\title{
KONTEKSTUALISASI HADIS PERNIKAHAN DALAM TRADISI ISLAM LOKAL: NYONGKOLAN DI LOMBOK
}

\author{
Nikmatullah \\ Institut Agama Islam Negeri Mataram \\ nikmahzayn@gmail.com
}

\section{Abstract}

Nyongkolan is one of the Islamic marriage seremony Sasak made by way of the procession the bride and her family along the way which aims to announce the wedding and the hospitality weaves between both parties. This tradition is acculturation between Islam with customary local of Sasak practiced by Muslims Sasak. As a devout muslim and religious fanatic, Sasak Muslims wedding announcement on hadith actualize in the form Nyongkolan. The spirit of hadith is about the procession that very accommodated towards local traditions. He as a form of harmonisation which brings together various elements: the religion, customs, and modernity. The music that accompanied the procession either kecimol, gendang beleq or rudat as the street entertainment for the surrounding communities. In the process, Nyongkolan is considered a problem as it causes blocked on the highway. This paper aims to described the tradition of Nyongkolan and acculturation between religion (hadith) and the custom in the tradition.

Keywords: Contextulization, Hadith, Weddings, Nyongkolan 


\section{Abstrak}

Nyongkolan adalah salah satu seremony perkawinan Islam Sasak yang dilakukan dengan cara arak-arakan pengantin dan keluarganya sepanjang jalan yang bertujuan untuk mengumumkan pernikahan dan menjalin silaturrahmi antara kedua belah pihak. Tradisi ini merupakan bentuk akulturasi antara Islam dengan adat lokal Sasak yang dipraktekkan oleh masyarakat muslim Sasak. Sebagai muslim yang taat dan fanatik dalam beragama, Muslim Sasak mengaktualisasikan hadis pengumuman pernikahan dalam bentuk Nyongkolan. Spiritnya dari hadis akan tetapi prosesinya sangat akomodatif terhadap tradisi lokal. Ia sebagai bentuk harmonisasi yang menyatukan berbagai elemen: agama, adat, dan modernitas. Musik yang mengiringi arakan baik berupa kecimol, gendang beleq atau rudat bagaikan hiburan jalanan bagi masyarakat sekitar. Dalam perkembangannya, Nyongkolan dianggap masalah karena menyebabkan macet di jalan raya. Tulisan ini bertujuan untuk mendiskripsikan tradisi Nyongkolan serta akulturasi antara agama (hadis) dan adat dalam tradisi tersebut.

Kata Kunci: Kontekstualisasi, Hadis, Pernikahan, Nyongkolan 


\section{A. PENDAHULUAN}

$\mathrm{H}$ adis sebagai sumber kedua ajaran Islam mempunyai peran yang sangat strategis bukan hanya sebagai penjelas al-Quran akan tetapi juga sebagai sumber hukum dan inspirasi agama. ${ }^{1}$ Hadis sebagaimana al-Quran bersifat universal yang berlaku bagi seluruh umat Islam di setiap tempat dan waktu, akan tetapi dalam dataran praktek beradaptasi dengan lokalitas dan keragaman budaya umat Islam. Kemampuan ajaran Islam untuk beradaptasi dengan tempat dan waktu justru semakin menguatkan universalitas Islam itu sendiri.

Akulturasi antara agama (hadis) dan adat menjadi salah satu point penting dalam kajian living hadis, yang diartikan sebagai praktek atau tradisi masyarakat yang terinspirasi dari teks hadis. Teks hadis tersebut dipahami kemudian dipraktekkan oleh masyarakat muslim dalam kehidupan sehari-hari. Tulisan ini fokus pada praktek perkawinan Islam Sasak yang terinspirasi dari hadis pernikahan, khususnya terkait dengan tradisi Nyongkolan. Nyongkolan adalah praktek dari teks hadis tentang mengumumkan pernikahan. Teks hadis tersebut diaplikasikan dan diimplementasikan oleh masyarakat Sasak sesuai dengan tradisi dan kearifan lokal setempat.

\section{B. PEMBAHASAN}

\section{Lombok dan tradisi Sasak}

Lombok yang terletak di wilayah Timur Indonesia juga dikenal dengan Pulau Seribu Masjid sebagai simbol dari religiusitas masyarakat setempat. Hal ini menunjukkan bahwa masyarakat Sasak sebagai suku asli Lombok sebagai pemeluk agama Islam yang sangat kuat dan fanatik. Kata Sasak atau saksak yang berarti hanya jalan lurus atau satu-satunya jalan yang harus dilalui untuk keselamatan dunia dan akhirat. Pendapat lain mengatakan bahwa Sasak berasal dari kata Sah artinya pergi dan Saka artinya leluhur. Sasak artinya pergi ke tanah

1 Kamaruddin Amin, Menguji Kembali Metode Kritik Hadis (Jakarta: Hikmah, 2009), 1 
leluhur. ${ }^{2}$

Dalam kehidupan sosial kemasyarakatan, Tuan Guru sebagai tokoh agama mempunyai peran yang sangat penting dalam masyarakat. Tuan guru adalah istilah lain dari kiai atau ulama. Mereka adalah orang yang memegang otoritas keagamaan dan berpengaruh terhadap sosial kemasyarakatan. Mereka ibarat teks yang hidup, dimana segala tutur kata dan perbuatannya diikuti oleh masyarakat. Seseorang yang disebut dengan tuan guru adalah orang yang mempunyai pemahaman kegamaan yang mendalam. Khusus lagi mereka adalah mereka yang pernah tinggal dan menimbah ilmu di Timur Tengah khususnya Mekkah dan Madinah. Pengakuan ini diperoleh dari masyarakat setempat yang menunjukkan eksistensi ketuanguruan mereka. Selain sering diundang untuk memberikan ceramah agama, mereka juga dipercaya mempunyai karomah, kelebihan-kelebihan yang luar biasa.

Selain dikenal sebagai masyarakat yang agamis, Lombok juga mempunyai banyak keragaman budaya dan adat. Keduanya, agama dan adat tidak terpisahkan. Dengan kata lain, adat bersendikan syara', syara' bersendikan kitabullah. Hal ini dipengaruhi oleh pola masuknya Islam di Lombok. Islam masuk ke Lombok pada abad XVI di bawa oleh wali dari Jawa, Sunan Prapen. Islam sebagai agama baru pada saat itu memberikan pengaruh yang sangat besar terhadap sosial budaya dan politik dalam masyarakat Sasak. Islam lebih mudah diterima oleh masyarakat Sasak karena perpindahan agama awal tidak menggunakan kekuatan yang radikal. Ia menggunakan metode sufisme dimana menekankan sebuah pendekatan mistis dan dianggap dekat dengan praktek-praktek peribadatan umum seperti ziarah ke kuburan para wali dan melakukan pembacaan zikir. ${ }^{3}$ Meskipun demikian, Islam di Lombok pada umumnya

2 Departemen Pendidikan dan Kebudayaan, Dampak Modernisasi terhadap Hubungan Kekerabatan di Nusa Tenggara Barat, NTB: Departemen Pendidikan dan Kebudayaan, 1983/1984.; Departemen Pendidikan dan Kebudayaan, Adat dan Upacara Perkawinan Daerah Nusa Tenggara Barat, Jakarta: Departemen Pendidikan dan Kebudayaan, 1978/1979.

3 John Ryan Bartholomew, Alim Lam Mim: kearifan Masyarakat Sasak diterjemahkan oleh Imron Rosyidi, Yogyakarta: Tiara Wacana, 2001, 92 
dipraktekkan dengan agak kaku dan bentuknya ortodoks bila dibandingkan dengan daerah lain. ${ }^{4}$

Islamisasi Lombok terjadi secara damai bebas dari kekerasan. Hal ini menujukkan bahwa wali atau sunan yang membawa Islam adalah orang yang berpengetahuan luas, shaleh, kharismatik dan terhormat serta diterima oleh masyarakat lokal. Mereka mempunyi perilaku yang baik dan sangat persuasif dalam menyampaikan pesan agama tetapi juga sangat toleran terhadap praktek adat lokal. ${ }^{5}$ Ajaran Islam disampaikan dengan mempertimbangkan pemahaman kontekstual masyarakat lokal Lombok. Sehingga sangat mudah untuk mendapatkan ritual simbolik yang merefleksikan Islam. Ritual tradisional dikreasikan menurut legenda sejarah dalam al-Quran dan hadis. Islam diperkenalkan dengan menggunakan symbol dan methapora yang menyatu dengan kultur lokal dan diinterpretasikan kedalam konteks lokal. Islam kemudian dikenalkan dengan karakteristik: sinkritik, mistis dan akomodatif terhadap pengaruh Hindu-Budha, dan praktek animistic. ${ }^{6}$

Di Lombok, Islam di kenal dalam dua corak yang berbeda: Islam waktu lima dan Islam Wetu Telu. Islam waktu lima adalah Islam sunni yang dipengaruhi oleh para Tuan Guru. Beberapa daerah dikenal sebagai daerah santri karena terdapat komunitas pondok pesantren yang menyebar hampir di seluruh wilayah Lombok. Misalnya daerah di Lombok Timur sebagai pusat organiasi keagamaan terbesar di Lombok, Nahdatul Wathan; Lombok Barat di Kediri dan Narmada; dan Kota Mataram. Sementara Islam wetu telu adalah Islam sinkritis yang masih sangat kental dengan budaya setempat. Yang terakhir ini lebih terkenal di daerah Bayan, Lombok Utara. Di sini, tokoh adat lebih berpengaruh dalam masyarakat dibandingkan dengan

\footnotetext{
4 John Ryan Bartholomew, Alim Lam Mim: kearifan Masyarakat Sasak diterjemahkan oleh Imron Rosyidi, Yogyakarta: Tiara Wacana, 2001, 86

5 Erni Budiwanti, Localized Islam In Lombok: Wali, Sacred Sites And Ziarah Tradition, Strategic Review Indonesia 360, October-December 2015/Volume 5/Number 4

6 Erni Budiwanti, Localized Islam In Lombok: Wali, Sacred Sites And Ziarah Tradition, Strategic Review Indonesia 360, October-December 2015/Volume 5/Number 4
} 
tokoh agama (Tuan Guru). Salah satu ikonnya adalah masjid Bayan, masjid yang sangat bersejarah perkembangan Islam di Lombok.

Secara umum, masyarakat Lombok masih mengenal stratifikasi sosial berdasarkan gelar kebangsawanan. Strata sosial Lombok terbagi menjadi tiga golongan yakni golongan para raja, ningrat atau raden, dan pruangase. Pertama, golongan para raja yang yang merupakan keluarga inti kerajaan yang bergelar datu atau pemban. Kedua, Golongan ningrat atau raden. Golongan ini dalam strata sosial Lombok disebut dengan menak yang terdiri dari raden dan dende, mamiq dan mamiq buling, serta lalu dan baiq atau mamiq dan lale. Ketiga, golongan pruangase sebagai rakyat biasa, yang bukan keturunan raja. Mereka adalah bape atau amaq dan inaq. Pemegang kasta yang terendah adalah golongan jajar karang atau bulu ketujur dan pengayah. ${ }^{7}$

Dengan demikian, pola keberagamaan (keberislaman) orang Sasak cukup variatif. Keragaman tersebut terkait dengan praktek dan interpretasi teks keagamaan. Secara umum, penganut Islam Waktu Lima pemahaman keislamannya lebih ortodok dibandingkan dengan Islam Wetu telu yang lebih bercorak sinkritis. Meskipun demikian, Penelitian Maria Plat menunjukkan bahwa daerah Lombok Barat yang menganut Islam Waktu Lima juga sinkritis kaitannya dengan penggunaan mantra dan kekuatan supranatural yang sangat mudah dijumpai dalam masyarakat. ${ }^{8}$ Mantra tersebut dipergunakan oleh masyarakat untuk urusan percintaan, dimana lakilaki yang berkeinginan untuk menikah dengan seorang perempuan, terkadang menggunakan mantra untuk memikat hati perempuan yang menarik hatinya.

7 Jamaluddin. Sejarah Sosial Islam Di Lombok Tahun 1740-1935 (Studi Kasus Terhadap Tuan Guru), Jakarta: Kemenag Balitbang Diklat, 2011, 168-169.

8 Maria Platt, 'It's Already Gone Too Far': Women and the Transition into Marriage in Lombok, Indonesia, The Asia Pacific Journal of Anthropology, 2012, 13:1, 76-90, 


\section{Akulturasi Islam dan adat lokal Nusantara}

Islam berkembang dan menyebar ke seluruh dunia sejak zaman Nabi Muhammad SAW hingga saat ini telah mengalami berbagai macam perkembangan. Secara normatif, ajaran Islam tidak berubah dan berlaku disepanjang masa. Akan tetapi, dalam tataran praktis, Islam yang berasal dari Arab kemudian menyebar ke seluruh penjuru dunia berinteraksi dengan berbagai budaya dunia. Seperti Islam yang masuk ke Indonesia dibawa oleh para pedagang dari Persia dan Gujarat berinteraksi dengan tradisi dan budaya lokal Indonesia. Konsekwensi dari interaksi tersebut adanya penolakan dan penerimaan terhadap Islam. Konflik misalnya terjadi dalam proses Islamisasi di Cirebon dan Jepara antara pedagang asing yang membawa agama dengan kaum bangsawan yang berkuasa pada saat itu. Sementara akomodasi Islam misalnya konversi seorang raja yang diikuti oleh para pengikutnya. Kemudian raja membuat kebijakan untuk membangun fasilitas ibadah dan lembaga pendidikan Islam. Akomodasi tersebut tercermin dari pengruh kesultanan Demak setelah keruntuhan kerajaan Majapahit tahun $1518 .^{9}$

Proses akomodasi kultural Islam memperlihatkan interaksi yang intens antara agama yang bersifat universal dengan nilai, norma, serta praktek sosial yang bersifat lokal. Islam tidak hanya mempertimbangkan tradisi tersebut dalam penyebarannya tetapi juga telah melakukan berbagai proses pembaharuan dengan pembentukan tradisi baru. Di satu pihak, Islam membiarkan proses kontekstualisasi Islam dengan realitas lokal terjadi dalam berbagai bentuk sejauh menghilangkan prinsip-prinsip Islam. Di lain pihak Islam telah memberikan corak dan sifat-sfat khas dalam berbagai dimensi kehidupan di berbagai tempat. ${ }^{10}$

Sebagai contoh adalah proses islamisasi di Jawa yang

9 Irwan Abdullah dan Azyumardi Azra, Islam dan Akomodasi, dalam Ensiklopedia Tematik Dunia Islam: Asia Tenggara, Jilid 5, Jakarta: Pt Ichtiar Baru Van Hoeve

10 Irwan Abdullah dan Azyumardi Azra, Islam dan Akomodasi, dalam Ensiklopedia Tematik Dunia Islam: Asia Tenggara, Jilid 5, Jakarta: Pt Ichtiar Baru Van Hoeve 
terjadi dalam empat proses. Pertama, proses pemasyarakatan warisan budaya istana yang halus dan adiluhung seperti seni pewayangan dan music gamelan. Kedua, kitab-kitab pesantren seperti naskah berbahasa Melayu bertulisan Jawa Pegon, atau naskah berbahasa Arab menjadi sumber dalam proses kreatif para pujangga dan sastrawan Jawa. Ketiga proses pencarian titik temu dua tradisi seperti penyatuan tahun Jawa dengan tahun Hijriyah dalam tradisi pesantren. Keempat, pelibatan istana dalam syiar Islam dalam pembangunan fasilitas agama seperti masjid.

Akomodasi Islam yang bersifat asimilatif ini membuat Islam lebih mudah diterima oleh masyarakat Indonesia. Para ulama menggunakan adat sebagai media untuk menyebarkan kepada masyarakat Indonesia. Sehingga dengan menggunakan tradisi lokal, Islam lebih mudah mengakar dalam masyarakat. Akibatnya, warna lokal dibandingkan dengan warna universalnya. Antropolog Robert Redfield memperkenalkan tentang tradisi besar (great tradition) dan tradisi kecil (little tradition). Dalam kaitannya dengan Islam, yang dimaksud dengan tradisi besar adalah Islam sebagai doctrinal-normatif sedangkan tradisi kecil adalah akualisasi Islam dalam realitas sosial, budaya, politik, ekonomi, dll. Yang disebutkan terakhir inilah yang kemudian dikenal dengan istilah tradisi lokal yaitu Islam yang mengejewantah dalam lingkungan masyarakat dan sosial budaya lokal tertentu. ${ }^{11}$ Saat ini diperkenalkan Islam Nusantara atau Islam Indonesia adalah Islam yang adaptif, pragmatik dan gradualistik serta sinkritik. ${ }^{12}$ Contohnya adalah tradisi Selamatan dalam masyarakat Jawa yang memadukan antara Islam dan tradisi lokal. ${ }^{13}$

11 Irwan Abdullah dan Azyumardi Azra, Islam dan Akomodasi, dalam Ensiklopedia Tematik Dunia Islam: Asia Tenggara, Jilid 5, Jakarta: Pt Ichtiar Baru Van Hoeve

12 Kees Van Dijk, Comparing Different Streams Of Islam Wrestling With Words And Definitions, dalam Jajat Burhanuddin Dan Kees Van Dijk (Edt), Islam in Indonesia: Contrasting Images and Interpretations, Amsterdam: Amsterdam University Press, 2013

13 Mark R Woodward, , The "Slametan": Textual Knowledge And Ritual Performance In Central Javanese Islam, History Of Religions; Aug 1, 1988; 28, 1; Proquest Pg. 54. Masdar Hilmy, Islam And Javanese Acculturation:Textual And Contextual Analysis Of The Slametan Ritual, A Thesis Subm Itted To The Faculty Of Graduate Studies An D Research In Partial Fulfillment Of The Requirements Of Th E Degree Of Master Of Arts, Institute Of Islamic Studies, McGill University Montreal Canada, 


\section{Kontekstualisasi Hadis Pernikahan}

Kata kontekstualisasi berasal dari kata konteks. Menurut kamus Besar Bahasa Indonesia, konteks adalah situasi yang ada hubungannya dengan kejadian. Kontekstual adalah sesuatu yang berhubungan dengan konteks. ${ }^{14}$ Sementara yang dimaksud dengan kontekstualisasi dalam pemahaman hadis adalah praktek pemahaman yang dilakukan secara tersirat. Pemahaman kontekstual menekankan dua dimensi konteks yang berbeda yaitu: pertama, konteks kemunculan hadis yang mencakup kondisi sosio-historis berupa kondisi, kultur, budaya masyarakat Arab. Konteks ini dapat dikaji melalui asbāb al-wurūd, sejarah kenabian, sejarah para perawi hadis atau al-rijāl al-hadìś, matan hadis dan literatur lainnya yang berkaitan dengan kondisi masyarakat pada saat hadis muncul. Kedua, memperhatikan konteks pada saat teks tersebut hendak dipahami. Pada tahap ini, perkembangan masyarakat, baik dari segi kultur, budaya, dan nilai yang tumbuh menjadi pertimbangan utama ketika melakukan kontekstualisasi pemahaman hadis. ${ }^{15}$ Adapun yang dimaksud dengan konteks hadis dalam tulisan ini adalah hadis yang ada hubungannnya dengan sosial budaya dimana hadis tersebut dipahami dan dipraktekkan oleh masyarakat setempat.

Kontekstualisasi hadis semakin penting mengingat kehidupan yang dijalani oleh umat Islam semakin berkembang dan bertambah kompleks permasalahannya. Oleh karena

1999; L.F. Brakel, Islam and local traditions: syncretic ideas and practices, Indonesia and the Malay World, 2004, 32:92, 5-20. Islam Jawa dibagi menjadi dua klasifikasi: the Sufi-scriptural tradition, representing pesisir (coastal regions)culture; and the interior culture, characterized by a mystical and syncretistic Hindu-Buddhist tradition.

14 http://kbbi.web.id/kontekstual . Sementara Masdar Hilmy menggnkan istilah tekstual dan kontekstual untuk melakukan pendekatan terhadap kajian tentang Selamatan. Yang dimaksud dengan pendekatan tekstual adalah pendekatan teks keagamaan sedangkan pendekatan kontekstual adalah dengan menggunakan perspektif analisis sosial budaya. Masdar Hilmy, Islam And Javanese Acculturation:Textual And Contextual Analysis Of The Slametan Ritual, A Thesis Subm Itted To The Faculty Of Graduate Studies An D Research In Partial Fulfillment Of The Requirements Of Th E Degree Of Master Of Arts, Institute Of Islamic Studies, McGill University Montreal Canada, 1999;

15 Pendekatan penafsiran hadis hampir sama dengan penafsiran Al-Quran. Model tersebut merupakan pendekatan yang dilakukan untuk menafsirkan Al-Quran. Lihat: Abdullah Saeed, Interpretating The Qur'an: Towards A Contemporary Approach (London Dan New York: Routledge, 2006), 50-3 
itu, pemaknaan suatu hadis diperlukan sebagai upaya untuk memberikan solusi terhadap berbagai persoalan yang dihadapi oleh umat Islam dalam kehidupan sehari-hari. Hal ini menunjukkan bahwa ajaran Islam şāliḥ li kull zamān wa makān sebenarnya menunjukkan fleksibilitas dan elastisitas ajaran, bukan ortodoksi yang ketat dan kaku. ${ }^{16}$

Kontekstualisasi hadis sebenarnya bukanlah persoalan baru dalam sejarah Islam. Pada fase-fase awal Islam, para sahabat tidak lama setelah Nabi wafat, dengan dimotori oleh Umar bin Khattab dan Uthman bin Affan, telah melakukan kontekstualisasi hadis. Umar bin Khaththab misalnya melakukan pengubahan sistem pembagian harta rampasan perang, tidak seperti yang dipraktikkan pada masa Nabi dan Abu Bakar. Demikian pula Usman yang menetapkan penggunaan bahasa suku Quraish sebagai rujukan dalam membuat kodifikasi yang ditetapkan sebagai sebagai mushaf standar. Dalam skala individu, kontekstualisasi hadis itu bahkan telah dilakukan sahabat di zaman Nabi sendiri. Buktinya, ketika mengirim dua utusan ke Bani Quraizah untuk menyelesaikan suatu urusan, Nabi berpesan agar mereka tidak melakukan shalat Ashar sebelum sampai di perkampungan salah satu bani kaum Yahudi itu. Di tengah perjalanan, karena waktu Ashar telah tiba, dan Bani Quraizah telah dekat, salah seorang dari utusan itu melakukan shalat. Difahaminya bahwa pesan Nabi dimaksudkan untuk mempercepat proses perjalanan saja. Sementara utusan yang satu baru melakukan shalat Ashar setelah sampai di tempat tujuan, sebagaimana yang dipesankan Nabi. ${ }^{17}$

Meskipun demikian, pemahaman tektual dan kontekstual sebenarnya bukan sebuah pemahaman yang terpisah satu dengan yang lain. Ada beberapa aspek dari ajaran agama yang memang harus dipahami secara tekstual dan sebagian lagi

16 Muhammadiyah Amin, Kontekstualisasi Pemahaman Hadis Dan Rekonstruksi Epistemologi IkhtiläF, Dalam Fiqh Al-Hadīś, Islamica, Vol. 5, No. 2, Maret 2011, 246

17 Muhammadiyah Amin, Kontekstualisasi Pemahaman Hadis Dan Rekonstruksi Epistemologi IkhtilāF, Dalam Fiqh Al-Hadīś, Islamica, Vol. 5, No. 2, Maret 2011, 246 
dipahami secara kontekstual. M. Syuhudi Ismail membagi lagi pemahaman hadis ini menjadi universal, temporal, dan lokal. Pembagian tersebut berdasarkan perbedaan bentuk matan hadis Nabi, ada yang berupa jawāmi' al-kalām, ungkapan yang singkat namun mempunyai makna yang padat, yang mempunyai varian bentuk tamsil, dialog, simbolik, dan analogi. Kandungan hadis juga dihubungkan dengan fungsi Nabi yang tidak hanya berperan sebagai Rasul akan tetapi juga sebagai manusia biasa, yang mempunyai multi peran. Beliau berperan sebagai Rasul, kepala negara, pemimpin masyarakat, panglima perang, hakim dan pribadi. Oleh karena itu, memahami sebuah hadis harus dikaitkan dengan peran beliau saat itu. ${ }^{18}$

Pemahaman kontekstualisasi selain mempertimbangkan konteks sosial historis kemunculan hadis (asbāb al-wurūd), juga mempertimbangkan konteks sosial budaya dimana hadis dipahami oleh masyarakat kontemporer saat ini. Pemahaman tersebut tidak hanya melihat perkembangan ilmu pengetahuan dan teknologi juga memperhatikan konteks lokal setempat. ${ }^{19}$

Pernikahan adalah sunnah Nabi. Umat Islam melaksanakan pernikahan berdasakan teks al-Quran dan hadis. Sebagai bagian dari ajaran, maka pernikahan dianjurkan untuk umat Islam. Akan tetapi dalam pelaksanaannya, proses dan ceremony pernikahan sangat dipengaruhi oleh konteks sosial budaya lokal umat Islam. Hal tersebut membuat praktek pernikahan cukup variatif di kalangan umat Islam. Ada yang menyelenggarakan dengan sederhana yang penting adalah memenuhi persyaratan rukun pernikahan sebagaimana perintah Allah, namun tidak sedikit yang melaksanakan dengan penuh kemeriahan, dengan biaya yang tinggi dan waktu yang panjang. Semuua tergantung tradisi dan budaya setempat.

Theodore Friend meneliti tentang ritual pernikahan di beberapa negara muslim: Indonesia, Pakistan, Arab Saudi,

18 M. Syuhudi Ismail, Hadis Nabi Yang Tekstual Dan Kontekstual: Telaah Ma'ani Al-Hadis Tentang Ajaran Islam Yang Universal, Temporal, Dan Lokal, (Jakarta: Bulan Bintang: 2009), 6

19 Inilah Yang Menjadi Latar Belakang Kemunculan Penelitian Living Hadis, dimana Hadis di respon, dipahami dan dipraktekkan oleh masyarakat Muslim. 
Iran dan Turki. Misalnya di Arab Saudi, ceremony pernikahan dilaksanakan antara tiga sampai tujuh hari. Ada dua tahapan yang dilalui yakni malam henna dan malam resepsi pernikahan. Malam henna adalah malam dimana pengantin perempuan menghias tangan ddan kakinya dengan henna. Sementara malam resepsi pernikahan diadakan di hotel atau rumah. Pengantin perempuan menggunakan pakaian putih atau yang lain, memakai perhiasan dan jilbab panjang serta dihiasai dengan bunga. Sementara di Pakistan, pengantin perempuan mengggunakan penutup wajah ketika akad nikah disertai dengan pesta tarian dan nyanyian yang di sebut dengan dhoki selama sebulan sebelum hari pernikahan dilaksanakan. ${ }^{20}$

Menurut Kalmijn, pernikahan di negara non-Barat, orang tua mempunyai peranan yang sangat penting untuk memilih pasangan bagi anak perempuannya dan perayaan pernikahan dilakukan dalam beberapa hari dan beberapa tahapan ritual yang harus dilalui. ${ }^{21}$ Pernikahan bukan hanya sebagai ekspressi kebahagiaan bagi pasangan pengantin dan keluarganya, tetapi juga mensosialisasikan peran baru pengantin dan identitas baru sebagai suami istri. Selain itu, ritual pernikahan juga menunjukkan adanya status sosial dan kegamaan serta norma sosial yang berlaku di masyarakat mempunyai peran yang sangat penting dalam ritual pernikahan.

Hal ini juga terjadi dalam adat perkawinan Sasak. Dalam perkawinan Sasak, ada beberapa ritual yang harus dilalui oleh pasangan pengantin yang melibatkan banyak orang. Mreka bukan hanya keluarga inti, ibu dan bapak saja akan tetapi juga keluarga besar dan masyarakat sekitar. Menjalankan prosesi adat pernikahan Sasak berarti merupakan tanggung jawab seluruh elemen masyarakat setempat, baik tokoh agama,tokoh masyarakat, tokoh adat, dan pemerintah desa/kelurahan.

Merarik atau kawin lari adalah salah satu cara adat

20 Theodore Friend, Woman, Man, and God in Modern Islam, Michigan/Cambridge UK: William B. Eerdmans Publishing Company, 2012, 1-1.6

21 Matthijs Kalmijn, Marriage Rituals as Reinforcers of Role Transitions: An Analysis of Weddings in the Netherlands, Journal of Marriage and Family, Vol. 66, No. 3 (Aug., 2004), pp. 582-594 
perkawinan Sasak yang cukup popular dalam masyarakat selain melamar/melakok/meminta, merondong/dijodohkan, meneken/ perempuan antar dirinya ke rumah laki-laki, dan ngukuh/ nyerah hukum artinya laki-laki yang nyerah hukum kepada perempuan. $^{22}$ Meraaik hanya awal dari beberapa tahapan prosesi yang harus dilakukan selanjutnya yakni 1) Selabar, 3) mesejati, 4) mbait wali; 5) Akad nikah; 6) Sorong serah; 7) Nyongkolan; 7) Bales nae. ${ }^{23}$

Selabar adalah pihak laki-laki melaporkan kejadian merari' tersebut kepada kepala dusun dimana pihak perempuan tinggal. Mesejati adalah ketika utusan laki-laki memberitahukan langsung kepada pihak perempuan tentang terjadinya merari' tersebut. Dalam hal ini akan membicarakan persoalan teknis perkawinan (penyelesaian adat, seperti jumlah mahar dan pesuke) atau masalah hukum terkait dengan penyelesasian perkawinan, artinya akad nikah segera dilangsungkan tanpa membahas adat terlebih dahulu. Setelah itu, mbait wali adalah permintaan keluarga laki-laki supaya wali dari pihak perempuan menikahkan anaknya secara Islami.

Selanjutnya, setelah selabar, mesejati dan mbait wali selesai, maka pihak laki-laki harus melunasi uang jaminan dan mahar, kemudian barulah diselenggarakan akad nikah. Akad nikah biasanya dilangsungkan di tempat laki-laki, akan tetapi sebagian masyarakat sudah membuat kesepakatan tentang tempat perkawinan dilangsungkan, di tempat perempuan atau laki-laki sesuai dengan kesepakatan. Mahar bisa dibayarkan pada saat akad nikah atau setelahnya, tergantung akad apakah dengan tunai atau tidak. Jumlah mahar ditentukan oleh pihak perempuan, meskipun hanya dengan segelas air. Dalam masyarakat berkembang anggapan bahwa air adalah simbol kehidupan. Air juga sebagai simbol bahwa perempuan tidak mau memberatkan laki-laki yang akan menjadi suaminya.

22 Tuti Harwati, Kearifan Lokal Masyarakat Sasak: Alternatif Pemecahan Permasalahan Perempuan Sasak, Dalam Atun Wardatun (Editor), Jejak Jender Pada Budaya Mbojo, Samawa Dan Sasak Di Nusa Tenggara Barat, Mataram: PSW IAIN Mataram, 2009, 95. Sementara dalam Islam WetuTelu secara umum hanya dikenal melalui tiga cara yakni perondangan, mepadik lamar, dan selarian.

23 M. Sa'i, Dosen IAIN Mataram, Wawancara Tanggal 7 November 2011 
Pesuke adalah pemberian sejumlah uang kepada perempuan yang dijadikan sebagai biaya untuk pelaksanaan acara begawe dipihak perempuan. Begawe ini adalah tasyakuran di keluarga perempuan atas penyelenggaraan akad nikah dipihak laki-laki.

Selanjutnya, Nyongkolan dan sorong serah dilakukan pada saat yang bersamaan yang dipimpin oleh pembayun, juru bicara dalam proses sorong serah. Nyongkolan adalah mengantarkan kembali pihak perempuan kepada keluarganya. Dalam acara ini, kedua pengantin diarak keliling kampung yang diiringi dengan musik tradisional gendang belek atau kecimol. Sorong serah yakni proses pembicaraan yang terkait dengan seluruh rangkaian perkawinan yang telah dilaksanakan. Pada saat inijuga dibicarakan tentang proses merariknya, apakah menyalahi adat atau tidak. Jika menyalahi adat, maka laki-laki akan dikenakan denda sesuai dengan kesepakatan adat kampung. Adat inilah yang dinamakan sebagai krame adat. Juru bicara sorong serah dikenal dengan nama pembayun. Ia akan menyampaikan maksudnya diiringi dengan tembang-tembang Sasak yang isinya seputar adat dan tata krama dalam berkeluarga. Terakhir adalah bales nae yaitu kunjungan pihak laki-laki kepada keluarga pengantin perempuan setelah acara nyongkolan dan aji krame. Acara ini bertujuan untuk memperkenalkan semua anggota keluarga terdekat dan silaturrahmi keluarga.

Merarik merupakan praktek yang dipengaruhi oleh Hindu Bali yang pernah menjajah Lombok pada awal abad 18 hingga pertengahan abad 19 sebagai cara bagi perempuan untuk memilih pasangannya atau sebaliknya cara laki-laki untuk menunjukkan kekuatannya. Hal ini dilakukan karena perempuan Sasak memiliki keleluassaan uuntuk menerima beberapa laki-laki untuk midang, berkunjung ke rumahnya. Karena mereka berkompetesi, maka laki-laki yang berani untuk melarikan perempuan tersebut dianggap sebagai pemenang. Jadi, merarik adalah simbol dari kejantanan laki-laki yyang berhasil merebut perempuan dari lakki-laki lain. ${ }^{24}$ Sebaliknya

24 Maria Platt, 'It's Already Gone Too Far': Women and the Transition into Marriage in Lombok, Indonesia, The Asia Pacific Journal of Anthropology, 2012, 13:1, 76-90 
bagi perempuan, kawin lari adalah bentuk agensi atu resistensi perempuan untuk menghindari pernikahan yang tidak diinginkan seperti perjodohan dan orang tua tidak setuju.

Perkawinan di Lombok merupakan perpaduan antara agama, adat dan juga hukum negara. ${ }^{25}$ Sebagai muslim, pernikahan masyarakat sasak harus memenuhi persyaratan agama yakni terpenuhinya rukun pernikahan. Rukun pernikahan tersebut adalah adanya mempelai laki-laki dan perempuan, mahar dan saksi.Akad nikah juga biasanya dilakukan di masjid. Sementara untuk prosesi adat, mereka memadukan antara nilai-nilai Islam dan tradisi lokal. Tradisi lokal tetap dipertahankan selama itu baik meskipun masih ada pro dan konttra dari ulama atau tuan guru setempat tentang beberapa adat yang dianggap tidak islami. Misalnya tradisi merarik yangtidak sesuai dengan Islam atau nyongkolan yang diangggap mengganggu penggguna jalan raya.

Sedangkan hukum negara terletak pada pencatatan pernikahan yang dilakukan oleh petugas KUA untuk memenuhi administrasi pemerintahan. Meskipun dalam kenyataannya tidak semua pernikahan tercatat karena bagi mereka yang taat beragama, yang penting pernikahan sudah sesuai dengan aturan agama. Pencatatan pernikahan tidak termasuk dalam rukun pernikahan. Akibatnya masih banyak terdapat pernikahan siri dan perceraian di bawah tangan. Perceraian cukup dilakukan secara tradisional, hanya cukup laki-laki mengatakan "cerai" maka perceraian terjadi. Perkawinan dianggap sebagai jodoh, dan perceraian dianggap sebagai takdir. Jika terjadi perceraian, maka dikatakan tidak jodoh. Konsep jodoh lebih merupakan rasionalisasi ketimbang merupakan pemikiran motivasi. Perkataan jodoh karenanya tidak mendorong orang berusaha lebih keras atau tidak membiarkan mereka kurang keras berusaha dalam keberhasilan perkawinan.

25 Arnis Rachmadani, Local Wisdom Tradisi Perkawinan Islam Wetu Telu sebagai Perekat Kerukunan Masyarakat Bayan, dalam Harmoni HARMONI Juli - September 2011, Jurnal Multikultural \& Multireligius Vol. X No. 3, 171 


\section{Prosesi Nyongkolan}

Nyongkolan adalah arakan rombongan pengantin lakilaki dan perempuan menuju rumah pengantin perempuan dengan cara jalan kaki berkeliling kampung atau menyusuri sepanjang jalan raya yang disertai dengan musik dan nyanyian. Pelaksanaan Nyongkolan setelah ada kesepakatan kedua belah pihak yang biasanya 2 hari hingga paling akhir yaitu hari ke-10 setelah perkawinan dilangsungkan.

Ada beberapa perbedaan adat antara pengikut Islam Waktu Lima dengan Islam Wektu Telu dalam tradisi Nyongkolan. Dalam adat Islam Waktu Lima, acara nyongkolan dilakukan setelah selesai adat sorong serah, sementara pada pengikut Islam Wektu Telu tradisi Nyongkolan dilaksanaan bersamaan waktunya dengan sorong serah. Acara Sorong serah dilakukan di rumah perempuan dan pada saat bersamaan rombongan pengantin dalam adat Nyongkolan juga menuju rumah perempuan. Jika sorong serah belum selesai dilakukan, maka mereka belum diizinkan untuk masuk ke rumah perempuan. Mereka harus menunggu beberapa saat hingga proses sorong serah selesai dilaksanakan.

Rombongan peserta Nyongkolan terbagi dalam beberapa kelompok, yakni pembawa makanan, pengantin perempuan dan pengiring perempuan, laki-laki dan pengiring laki-laki, dan terakhir penyanyi dan pemain musik yang mengiringi pengantin. Rombongan terdiri dari keluarga, kerabat, sahabat, dan masyarakat sekitar yang mau berpartisipasi dalam acara tersebut. Jika tidak terlibat, masyarakat akan memeriahkan tradisi tersebut dengan cara melepas mereka di kampong atau menunggu rombongan Nyongkolan tersebut di kediaman perempuan. Laki-laki dan perempuan baik dewasa, remaja maupun anak-anak dengan penuh rasa suka cita mengiringi pengantin yang sedang berbahagia. Mereka berjalan kaki menuju rumah pengantin perempuan. Rombongan laki-laki dan perempuan diatur secara terpisah. Rombongan pengantin perempuan berada di depan dan pengantin laki-laki di belakang. 
Dalam adat Islam Wetu Telu di Bayan, pengantin di usung di atas tandu. ${ }^{26}$

Pakaian mereka berwarna-warni. Pengantin perempuan menggunakan kebaya dengan hiasan kepala (payas) yang dipayungi oleh perempuan pendampingnya. Sedangkan para pengiring perempuan menggunakan pakaian adat Sasak atau kebaya modern yang dipadukan dengan jilbab dengan corak berwarna warni atau sanggul tradisional. Sementara untuk alas kaki mereka menggunakan sepatu, sandal atau tidak memakai alas kaki sama sekali meskipun mereka harus berjalan ratusan meter. Sementara pengantin laki-laki juga menggunakan pakaian khas tradisional Sasak: sapuq dodot dan kereng belo. Sapuq sebagai pengikat kepala yang terbuat dari kain dengan ujungnya menonjol ke atas sebagai simbol keagungan Tuhan, sementara dodot adalah pengikat pinggang sebagai penahan kereng belo (kain panjang) yang ujungnya menunjuk ke bawah sebagai simbol sifat tawadhu nya kepada Tuhan. Para pengiring laki-laki juga mengunakan pakaian adat yang biasanya juga tanpa menggunakan alas kaki.

Para pengiring lain yang terdiri dari pembawa makanan dan sayur-sayuran serta pemain musik dan penari juga terpisah. Pengiring pembawa makanan berada diurutan paling depan rombongan, terdiri dari para remaja laki-laki dan perempuan. Barang bawaan tersebut diletakkan dalam besek yang di bawa oleh remaja perempuan atau dalam rumah-rumahan yang dibuat dari papan yang ditanggul oleh para remaja laki-laki. Sementara pemain musik dan penyanyi berada di deretan paling belakang. Ada tiga jenis musik yang sering digunakan dalam tradisi Nyongkolan yaitu kecimol, gendang beleq dan rudat. Musik yang umum digunakan adalah kecimol tetapi jika keluarga pengantin mempunyai kemampuan lebih, maka mereka juga menyewa gendang beleq dan rudat. Dalam urutan rombongan, pemain musik dan penari dipisahkan oleh para

26 Arnis Rachmadani, Local Wisdom Tradisi Perkawinan Islam Wetu Telu sebagai Perekat Kerukunan Masyarakat Bayan, dalam Harmoni HARMONI Juli - September 2011, Jurnal Multikultural \& Multireligius Vol. X No. 3, 171 
rombongan lain. Misalnya pemain rudat berada di belakang pembawa makanan atau urutan kedua rombongan, kemudian diikuti dengan gendang beleq di belakang rombongan pengantin perempuan atau urutan ke empat, serta penyanyi kecimol diurutan paling belakang.

Kecimol adalah kelompok alat musik yang terdiri dari rebana dan drum dan kadang-kadang dilengkapi dengan bilah kentongan atau dinamakan kul-kul yang dimainkan oleh lakilaki. Alat ini dilengkapi dengan sound atau speaker dan diringi oleh seorang penyanyi perempuan yang menyanyikan lagulagu dangdut atau lagu-lagu tradisional Sasak. Sementara gendang beleq adalah alat musik tradisional yang terdiri dari gong, terumpang, pencek dan seruling yang dimainkan dengan cara ditabuh dan dimainkan secara berkelompok.

Sepanjang jalan yang dilalui, rombongan Nyongkolan selalu disambut dengan gegap gempita oleh masyarakat sekitar. Mereka biasanya bertanya-tanya tentang identitas pengantin: siapa yang menikah, dengan siapa, darimana, dll. Akan tetapi yang lebih penting lagi adalah mereka merasa terhibur dengan bunyi musik dan nyanyian yang sangat merdu disenandungkan oleh para penyanyi kecimol atau rudat. Atau mereka sangat terkesima dengan tarian dan musik Gendang Beleq. Hiburan gratis dan menyenangkan bagi mereka.

Sementara anggota rombongan juga ikut menikmati musik dan nyanyian. Mereka berjoget sendiri-sendiri atau bersamasama dengan teman-teman yang lain. Ada juga yang meminum minuman keras untuk menjaga stamina dan tidak kenal lelah untuk berjoget. Terkadang juga penonton ikut joget bersamasama mereka. Sungguh sangat meriah.

Kedatangan mereka disambut secara besar-besaran oleh serombongan penyambut yang terdiri atas anak-anak, gadis, pemuda maupun orang tua. Upacara nyongkol dianggap selesai apabila anggota rombongan kesenian berupa kelentang, penabuh gamelan telah disuguhi minuman ala kadarnya. Setelah 
sampai di rumah pengantin perempuan, maka di tengahtengah tempat jajanan dan buah-buahan (dulang), sebagai wujud kesetiaan maka mereka saling menyuapi yang disebut Hamukti Ketresnan.

Setelah itu kedua mempelai dipersilahkan mengganti pakaiannya dengan acara "bedudus". Pada acara bedudus kedua mempelai dimandikan dengan air rampai yang telah disediakan. Maksudnya agar kedua mempelai selamat dalam menempuh hidup baru. Pada saat itu juga kedua calon pengantin kembali pulang diantar oleh rombongan dan iringan kesenian. ${ }^{27}$

Sekembalinya dari nyongkol kedua calon pengantin memasuki upacara kecil lagi disebut "bedak keramas". Upacara ini dilakukan di rumah calon pengantin laki-laki dan di pimpin oleh inak belian (tabib). Berikutnya inak belian mengeramasi kepala kedua mempelai dengan lengeh yaitu adonan kelapa parut dicampur kunyit serta beras kencur. Bedak lengeh yang digunakan dalam upacara tersebut, sebelumnya diberikan mantra oleh kyai kampung. Setelah keduanya dibedakkeramasi, keduanya dipersilahkan membersihkan diri, untuk selanjutnya keduanya kembali siap untuk memasuki "akad nikah". Upacara akad nikah (ngawinang) dilakukan di dalam kampu.

Waktu prosesi akad nikah juga berbeda antara Islam Wetu Telu dan Islam Waktu Lima. Jika Islam Wektu Telu melaksanakan akad nikah setelah Nyongkolan, sementara dalam Islam Waktu Lima sebaliknya. Tata cara pelaksanaan akad nikah dilakukan secara Islam, ada khuthbah nikah dan ijab kabul yang dilakukan oleh wali pengantin perempuan dengan pengantin laki-laki. Secara umum dalam masyarakat Sasak, khutbah nikah dibacakan dalam bahasa Arab sedangkan ijab kabul dalam bahasa Sasak atau bahasa Indonesia.

Nyongkolan dilakukan di jalan-jalan kampong atau jalan raya. Jika dilaksanakan di jalan raya, maka polisi dan laki-laki

27 Arnis Rachmadani, Local Wisdom Tradisi Perkawinan Islam Wetu Telu sebagai Perekat Kerukunan Masyarakat Bayan, dalam Harmoni HARMONI Juli - September 2011, Jurnal Multikultural \& Multireligius Vol. X No. 3, 171 
dewasa ikut menertibkan acara tersebut. Mereka mengatur jalannya rombongan agar berjalan dengan tertib dan hanya menggunakan sebagian jalan raya serta juga mengatur jalannya lalu lintas yang ditutup sebagian. Layaknya aparat, mereka membuka tutup lalu lintas yang tersendat dan macet. Sebagian pengguna jalan raya ikut menikmati totontonan gratis tersebut terutama bagi wisatawan yang tertarik dengan keunikan budaya lokal setempat. Itu adalah momen bagi mereka untuk mendokumentasikan proses berjalannya tradisi perkawinan Sasak Lombok. Namun bagi sebagain lainnya terutama bagi pengguna jalan yang mempunyai keperluan dan kepentingan lain, maka Nyongkolan dianggap sebagai bagian dari problem besar yang sangat mengganggu perjalanan mereka. Hal terjadi terutama bagi pengguna jalan raya menuju ke Bandara di Lombok Tengah.

Dalam tradisi Sasak, prosesi pernikahan harus dilakukan di rumah laki-laki. Setelah adat perkawinan selesai, mempelai perempuan di antar ke rumahnya melalui tradisi Nyongkolan. Tradisi ini juga dilakukan untuk mengumumkan kepada masyarakat bahwa pasangan tersebut telah sah sebagai pasangan suami istri. Rombongan nyongkolan harus berjalan kaki sekitar $1 \mathrm{KM}$ menuju rumah penga ntin perempuan. Jika tempat tinggal kedua pasangan berjauhan, maka rombongan keluarga pengantin di bawa naik truk atau mobil bak terbuka kemudian jalan kaki menjelang tempat tinggal perempuan. Nyongkolan biasanya dilakukan pada hari sabtu dan minggu atau hari libur pada waktu sore hari setelah selesai shalat ashar sampai menjelang maghrib.

\section{Kontekstualisasi hadis dalam adat Nyongkolan}

Nyongkolan adalah bentuk dari aktualisasi hadis dalam adat perkawinan Sasak. Sebagaimana tekah disebutkan di atas bahwa masyarakat muslim Sasak adalah orang yang sangat taat dan fanatik dalam beragama. Ketaatan tersebut dibuktikan 
dengan kehati-hatian mereka dalam menjalankan kehidupan sosial keagamaan terutama menyangkut pernikahan. Mereka berpegang peguh pada aturan syariah yang tertuang dalam fiqh yang bersumber dari al-Quran, hadis Nabi dan pendapat para ulama. Misalnya pada praktek pernikahan dan perceraian. ${ }^{28}$

Pernikahan adalah salah satu untuk menghindari zina dan dosa dikalangan remaja. Penelitian Linda Rae Bennett menunjukkan bahwa zina adalah tabu dalam masyarakat Sasak. ${ }^{29}$ Meskipun ada perbedaan toleransi antara laki-laki dan perempuan. Perempuan yang berzina bukan hanya di anggap berdosa tetapi juga menerima sanksi sosial berupa stigma tidak perawan lagi dan mempermalu keluarga. Oleh karena itu, perempuan yang pulang malam bersama laki-laki atau laki-laki midang ${ }^{30}$ kerumah perempuan diatas jam 10 malam, maka mereka dicurigai telah melakukan pelanggaran terhadap norma masyarakat dan martabat keluarga, maka mereka akan segera dikawinkan. Alternatif lain, mereka remaja putra dan putri tersebut akan segera merarik.

Percerian yang dilakukan oleh suami baik secara langsung maupun tidak dianggap sudah jatuh talak. Talak tersebut dianggap sah meskipun suami melakukannnya dengan kondisi marah atau hanya sekedar lewat SMS saja. Perceraian melalui

28 Jocelyn Grace meneliti tentang perkawinan dan perceraian dilakukan di perkampungan di Lombok Timur dikatakannya sebagai masyarakat yang heterogen dan komplek dan diidentifikasi sebagai penganut Islam ortodok. Secara formal, perkawinan dan perceraian diatur oleh aturan adat, hukum Islam dan hukum negara yang terkadang saling bertolak belakang. Area kontestasi antara hokum Islam atau hokum negara ditaati dengan mempertimbangkan adat lokal, status sosial ekonomi dan budaya setempat. Sementara hokum formal dan aturan pemerintah tentang hal tersebut dapat diinterpretasikan di tingkat lokal. Interpretasi inilah yang membuat hasil yang bervariasi dan mengakomodasi berbagai kepentingan politik ideology di Lombok. Grace, Jocelyn, "Sasak Women Negotiating Marriage, Polygyny and Divorce in Rural East Lombok," Intersection: Gender, History and Culture in the Asian Context, Issue 10, August, 2004

29 Linda Rae Bennett, Women, Islam and Modernity: Single Women, Sexuality and Reproductive Health in Contemporary Indonesia (London: Routledge/Curzon, 2005)

30 Maria Platt dengan studi etnografi Married Men Behaving Badly: Islam, Gender and Extramarital Relationships in Eastern I ndonesia membahas tentang praktek midang atau pacaran lagi bagi laki-laki yang sudah beristri yang mempunyai kontribusi terhadap tingginya angka kawin-cerai dalam masyarakat Sasak Lombok. Menurutnya, pacaran lagi merupakan interpretasi masyarakat lokal terhadap ajaran Islam. Pacaran lagi merupakan jalan bagi laki-laki untuk melakukan poligami hingga empat istri sebagaimana yang diperbolehkan oleh Islam. Islam dipahami oleh masyarakat lokal dengan bias gender dan cenderung misoginis. Maria Platt, Married Men Behaving Badly: Islam, Gender and Extramarital Relationships in Eastern Indonesia, Intersections: Gender and Sexuality in Asia and the Pacific Issue 28, March 2012 
pengadilan baru dilakukan jika pihak perempuan berkeinginan untk menikah lagi. Posisi perempuan dan keluarganya sangat lemah dalam kasus perceraian. Mereka tidak menuntut suami yang menjatuhkan talak atau pihak keluarga melakukan klarifikasi terhadap talak tersebut karena perceraian adalah hak suami. Perceraian yang sudah dijatuhkan oleh suami adalah sah dan jika mereka berkumpul lagi sebagai pasangan suami sitri, maka statusnya mereka berzina. Perzinahan adalah sangat dihindari oleh masyarakat Sasak. Karena menurut ajaran Islam, zina adalah dosa besar. Meskipun talak juga bukan berarti baik menurut pandangan agama akan tetapi talak diperbolehkan.

Demikian juga dnegan Nyongkolan. Nyongkolan adalah bentuk implementasi dari hadis Nabi untuk mengumumkan pernikahan. Pernikahan tersebut harus disertai dengan musik dan nyanyian:

$$
\text { اشيدوالنكاح واعلنوه }
$$

"Kumandangkanlah pernikahan dan umumkanlah ia"31

$$
\text { فصل ما بين الحرام والحلال الدف و الصوت }
$$

"Perbedaan antara yang haram dan yang halal ialah adanya rebana dan suara"32

\section{Harmonisasi dalam tradisi Nyongkolan}

Menurut Kalmijn, jika pasangan pengantin bisa melaksanakan ritual perkawinan sosial, yakni perayaan perkawinan yang melibatkan orang banyak, maka mereka mengumumkan keputusan menikah kepada orang lain melalui tiga pesta dalam satu peristiwa penting: relasi sosial, gereja dan Tuhan. ${ }^{33}$ Dengan disaksikan oleh orang lain, maka pasangan tersebut bisa meningkatkan komitmennya untuk saling

31 HR. Thabrani, Şa冈i冈 Al-Jami' Ash-Shaghir, Hadis No. 1022

32 HR. Al Tirmidzi, Sunan Al-Tirmidzi, Kitab Al-Nikah Bab I'lan Al-Nikah Hadis No. 869

33 Matthijs Kalmijn, Marriage Rituals as Reinforcers of Role Transitions: An Analysis of Weddings in the Netherlands, Journal of Marriage and Family, Vol. 66, No. 3 (Aug., 2004), pp. 582-594 
memiliki dan menjalani peran yang baru. Dengan komitmen baru berarti juga mengurangi rasa kekahwatiran terhadap masa depan perkawinan mereka.

Dalam kaitannya dengan Nyongkolan, ia adalah bentuk implementasi dari ajaran agama, hadis yang menyerukan agar umat Islam mengumumkan pernikahannya kepada khalayak ramai. Pengumuman ini bukan hanya untuk menunjukkan bahwa kedua pasangan telah menjadi suami istri dan siap mengarungi rumah tangga, akan tetapi juga Nyongkolan sebagai ajang untuk menjalin silaturrahmi, kerjasama dan hiburan. Silaturrahmi terjalin antar anggota keluarga. Mereka saling kenalan dan menjalin sebuah keluarga besar melalui institusi pernikahan. Silaturrahmi juga terbina dengan para kerabat dan sahabat. Saling berkunjung dan saling menyapa, reuni, temu kangen semua bisa terjadi dalam tradisi Nyongkolan.

Kerjasama juga dapat dijalin melalui Nyongkolan. Masyarakat bahu membahu, saling membantu untuk menyukseskan prosesi ini. Semua berbagi peran, siapa melakukan apa. Ada yang membawa makanan, ada yang mengiring pengantin, ada yang mengatur lalu lintas, ada yang berperan sebagai penghibur, dsb. Hiburan bagi semua kalangan, lintas generasi, semua strata sosial. Hiburan yang menyenangkan ditengah kesibukan dan peliknya persoalan kehidupan.

\section{KESIMPULAN}

Meskipun Nyongkolan mempunyai dampak negatif bagi pengguna jalan karena menjadi penyebab kemacetan akan tetapi ia adalah sebuah kearifan lokal yang perlu dilestasikan ditengah gempuran budaya global saat ini. Kearifan lokal masyarakat Sasak dalam menyatukan antara agama dan adat, antara tradisonalitas dan modernitas. 


\section{DAFTAR PUSTAKA}

Abdullah, Irwan dan Azyumardi Azra, Islam dan Akomodasi, dalam Ensiklopedia Tematik Dunia Islam: Asia Tenggara, Jilid 5, Jakarta: Pt Ichtiar Baru Van Hoeve

Amin, Kamaruddin, Menguji Kembali Metode Kritik Hadis, Jakarta: Hikmah, 2009

Amin, Muhammadiyah, Kontekstualisasi Pemahaman Hadis\{ Dan Rekonstruksi Epistemologi IkhtilāF, Dalam Fiqh Al-H\{AdīTh, Islamica, Vol. 5, No. 2, Maret 2011

Bartholomew, John Ryan, Alim Lam Mim: kearifan Masyarakat Sasak diterjemahkan oleh Imron Rosyidi, Yogyakarta: Tiara Wacana, 2001

Linda Rae Bennett, Women, Islam and Modernity: Single Women, Sexuality and Reproductive Health in Contemporary Indonesia, London: Routledge/Curzon, 2005

Brakel, L.F., Islam and local traditions: syncretic ideas and practices, Indonesia and the Malay World, 2004, 32:92, 5-20.

Budiwanti, Erni, Localized Islam In Lombok: Wali, Sacred Sites And Ziarah Tradition, Strategic Review Indonesia 360, OctoberDecember 2015/Volume 5/Number 4

Burhanuddin, Jajat dan Kees Van Dijk (Edt), Islam in Indonesia: Contrasting Images and Interpretations, Amsterdam: Amsterdam University Press, 2013

Departemen Pendidikan dan Kebudayaan, Dampak Modernisasi terhadap Hubungan Kekerabatan di Nusa Tenggara Barat, NTB: Departemen Pendidikan dan Kebudayaan, 1983/1984

Departemen Pendidikan dan Kebudayaan, Adat dan Upacara Perkawinan Daerah Nusa Tenggara Barat, Jakarta: Departemen Pendidikan dan Kebudayaan, 1978/1979 
Friend,Theodore, Woman, Man, and God in Modern Islam, Michigan/ Cambridge UK: William B. Eerdmans Publishing Company, 2012

Grace, Jocelyn, "Sasak Women Negotiating Marriage, Polygyny and Divorce in Rural East Lombok," Intersection: Gender, History and Culture in the Asian Context, Issue 10, August, 2004

Hilmy, Masdar, Islam And Javanese Acculturation:Textual And Contextual Analysis Of The Slametan Ritual, A Thesis Subm Itted To The Faculty Of Graduate Studies An D Research In Partial Fulfillment Of The Requirements Of Th E Degree Of Master Of Arts, Institute Of Islamic Studies, Mcgill University Montreal Canada, 1999;

Ismail, M. Syuhudi, Hadis Nabi Yang Tekstual Dan Kontekstual: Telaah Ma'ani Al-Hadis Tentang Ajaran Islam Yang Universal, Temporal, Dan Lokal, Jakarta: Bulan Bintang: 2009

Jamaluddin. Sejarah Sosial Islam Di Lombok Tahun 1740-1935 (Studi Kasus Terhadap Tuan Guru), Jakarta: Kemenag Balitbang Diklat, 2011

Kalmijn, Matthijs, Marriage Rituals as Reinforcers of Role Transitions: An Analysis of Weddings in the Netherlands, Journal of Marriage and Family, Vol. 66, No. 3 (Aug., 2004)

Platt, Maria, 'It's Already Gone Too Far': Women and the Transition into Marriage in Lombok, Indonesia, The Asia Pacific Journal of Anthropology, 13:1

Platt, Maria, Married Men Behaving Badly: Islam, Gender and Extramarital Relationships in Eastern Indonesia, Intersections: Gender and Sexuality in Asia and the Pacific Issue 28, March 2012

Rachmadani, Arnis, Local Wisdom Tradisi Perkawinan Islam Wetu Telu sebagai Perekat Kerukunan Masyarakat Bayan, dalam Harmoni HARMONI Juli - September 2011, Jurnal Multikultural \& Multireligius Vol. X No. 3, 171 
Saeed, Abdullah, Interpretating The Qur'an: Towards A Contemporary Approach London Dan New York: Routledge, 2006

Woodward, Mark R, The "Slametan": Textual Knowledge And Ritual Performance In Central Javanese Islam, History Of Religions; Aug 1, 1988

Wardatun, Atun (Editor), Jejak Jender Pada Budaya Mbojo, Samawa Dan Sasak Di Nusa Tenggara Barat, Mataram: PSW IAIN Mataram, 2009

http://kbbi.web.id/kontekstual . 